\title{
11
}

\section{What Psychological Science Knows About Achieving Happiness}

S. Katherine Nelson

University of California, Riverside

Jaime L. Kurtz

James Madison University

Sonja Lyubomirsky

University of California, Riverside

\footnotetext{
W ntrenched in both ancient and modern cultural tradition, the pursuit of happiness is a popular preoccupation around the world (Diener, 2000). Despite the centrality of this goal, the path to happiness is anything but obvious, in part because people are notoriously inaccurate at knowing what will make them lastingly happy (Wilson \& Gilbert, 2005). This lapse in self-knowledge can lead to poor choices, both in the short-term and in the long-term. After years spent saving for a larger house, trying to achieve a promotion, or finally being able to retire and move to the beach, individuals may be frustrated and baffled to discover that lasting happiness still manages to elude them. To demystify the determinants of happiness,
} 
people seek insight and advice from a vast range of sources, whichunfortunately—vary tremendously in credibility.

For example, people often turn to the self-help literature, which has capitalized on readers' deep-seated desire for happiness. Amazon.com currently boasts more than 6,000 titles in the categories "happiness" and "self-help," and many of these achieve best-seller status. Unfortunately, the vast majority of self-help books are not based on empirical evidence, and the casual reader can easily be taken in and ultimately frustrated by their quick-and-easy paths to lasting happiness.

Fortunately, with the emergence of positive psychology (Seligman \& Csikszentmihalyi, 2000), the scientific study of happiness desperately missing from self-improvement manuals has become a priority. Numerous investigations have provided empirical evidence for what does-as well as what does not-promote well-being.

\section{What Is Happiness?}

Before describing what psychological scientists have learned about the keys to happiness, it is important to unpack exactly what we mean by the term and how it is empirically investigated. Researchers have been theorizing about the causes, correlates, and consequences of happiness for more than three decades (Diener, 1984; Diener, Suh, Lucas, \& Smith, 1999; Ryan \& Deci, 2001; Ryff, 1989). According to the most frequently used definition, happiness (also known as subjective well-being) comprises both an affective component (i.e., the experience of relatively frequent positive and relatively infrequent negative emotions) and a cognitive component (i.e., relatively high life satisfaction or a positive overall evaluation of one's life) (Diener, 1984; Diener et al., 1999). Throughout this chapter, we use the terms happiness and subjective well-being interchangeably.

\section{How Do Psychological Scientists Study Happiness?}

A great deal of research has contributed to the scientific understanding of the paths to achieving happiness. Three general approaches to studying happiness involve 1) need and goal satisfaction theories, 2) genetic and personality predisposition theories, and 3 ) process or activity theories (see Diener, Oishi, \& Lucas, 2009, for a review). Need satisfaction and goal theories posit that pursuing appropriate goals and satisfying fundamental human needs will result in happiness. For example, self-determination 
theory holds that human beings have basic needs for autonomy, competence, and relatedness (Deci \& Ryan, 2000), and the fulfillment of these needs is associated with greater well-being (Sheldon et al., 2010). A second approach involves studying how people's genes and personality traits relate to their happiness levels. For example, studies have found that well-being has a strong genetic component (Lykken \& Tellegen, 1996), is closely linked to the personality traits of extraversion and neuroticism (Diener, \& Lucas, 1999), and is relatively stable over time (Diener, Sandvik, Seidlitz, \& Diener, 1993). Finally, process and activity theories, which motivate the research at the heart of this chapter, emphasize the potential to improve well-being by engaging in effortful activities (e.g., Lyubomirsky \& Layous, 2013; Lyubomirsky, Sheldon, \& Schkade, 2005; Seligman, Steen, Park, \& Peterson, 2005).

Although much work on well-being is correlational (e.g., comparing the average happiness of different types of individuals), we will primarily focus on the results of experimental research-specifically, positive activity interventions. These studies are primarily longitudinal in nature, examining the effectiveness of an intervention over the course of several weeks or months. Participants are typically randomly assigned to complete either an activity believed to promote happiness or a control (neutral) activity. Then, the participants' well-being is tracked regularly and systematically over time. Such studies, a specific type of randomized controlled trial, are considered the gold standard in experimental approach, as they represent the only design that allows researchers to determine causality.

As discussed above, participants in randomized controlled trials are assigned to either a treatment group (e.g., to express gratitude each week) or to a control group (e.g., to list what they did each week). Because this design increases the likelihood that any potentially relevant individual differences at the beginning of the experiment (e.g., the possibility that people in one group may be more motivated or less happy to begin with) will be equivalent across the treatment and control group, it increases the likelihood that any differences between groups by the end of the experiment can be attributed to the manipulation-in our case, the delivery of a positive activity intervention (e.g., the expression of gratitude). Randomized controlled trials are critical to understanding how people can reach greater levels of happiness. Just as the effectiveness of medical treatments must be established prior to their dissemination, potential positive activities require experimental empirical support before psychologists can confidently recommend to happiness seekers which strategies reliably boost happiness. 


\section{Review of Research on Well-Being}

\section{Is It Possible to Become Happier?}

Some research suggests that people cannot become sustainably happier because happiness levels are, in part, due to genetic factors (Lykken \& Tellegen, 1996; Nes, Roysamb, Tambs, Harris, \& Reichborn-Kjennerud, 2006), personality influences (Diener \& Lucas, 1999; McCrae \& Costa, 1990), and human beings' tendency to adapt to any positive life changes (Frederick \& Loewenstein, 1999; Lyubomirsky, 2011). Despite these sources of pessimism, other work provides evidence that happiness can indeed be enhanced and sustained. For example, research indicates that happiness is not always constant across a person's lifetime (Fujita \& Diener, 2005), and personality traits correlated with happiness, such as neuroticism, can change in adulthood (Helson, Jones, \& Kwan, 2002; Roberts, Walton, \& Viechtbauer, 2006). In addition, studies suggest that well-being can be improved via lifestyle changes, such as implementing a new exercise routine or improving one's nutrition (Walsh, 2011), and by engaging in positive activities, such as performing acts of kindness, becoming more grateful, or practicing optimism (see Sin \& Lyubomirsky, 2009, for a metaanalytic review, or "study of studies").

To reconcile and integrate the sometimes conflicting findings regarding the determinants of happiness, Lyubomirsky, Sheldon et al. (2005) developed the sustainable happiness model. They argue that, although more than half of individual differences in happiness are due to people's genetics, personalities, and life circumstances-all factors that are relatively immutable-intentional activities likely account for a large portion of individual differences in happiness. That is, how people think (e.g., whether they think optimistically or gratefully) and what they do (e.g., whether they practice forgiveness or do kind acts for others) in their daily lives can play a large role in how happy they are. In sum, the sustainable happiness model suggests that people can exercise a substantial amount of control over their well-being (Lyubomirsky, 2008).

\section{Empirically Supported Ways to Become Happier}

Early research attempting to understand how people can improve their happiness levels relied on comparing happy people to their less happy peers. Such cross-sectional, or correlational, studies found that happy 
people are relatively more likely to express gratitude for the good things in their lives (McCullough, Emmons, \& Tsang, 2002), to act more generously toward others (Krueger, Hicks, \& McGue, 2001; Lucas, 2001), and to think more optimistically about their futures (Lucas, Diener, \& Suh, 1996; Lyubomirsky, Tkach, \& DiMatteo, 2006). In general, happy people were found to construe information in more positive ways than their less happy peers (see Lyubomirsky, 2001, for a review). In sum, it appears that happy and unhappy people think about and approach their environments differently.

These studies provide some insight into the cognitions (e.g., thinking about the world optimistically) and behaviors (e.g., performing kind acts) that might improve happiness. However, because they are correlational, the direction and source of causality cannot be determined. For example, if happy people report being more optimistic, does this mean that optimism causes happiness, that happiness causes optimism, or a third variable (e.g., a nurturing parent) causes both?

To address the problems inherent in correlational designs, scientists have increasingly relied on experimental research-the randomized controlled studies described above-to pinpoint the determinants of happiness. For example, after first identifying some of the differences in cognition and action between happy and unhappy people, researchers then began to randomly assign participants to engage in these patterns of thought and behavior to establish their causal role in improving happiness. A number of such activities have now been identified as effective ways for people to increase their happiness. These include counting one's blessings (Chancellor, Layous, \& Lyubomirsky, 2013; Emmons \& McCullough, 2003; Froh, Sefick, \& Emmons, 2008; Lyubomirsky, Sheldon et al., 2005; Seligman et al., 2005), writing letters of gratitude (Boehm, Lyubomirsky, \& Sheldon, 2011a; Layous, Lee, Choi, \& Lyubomirsky, 2013; Lyubomirsky, Dickerhoof, Boehm, \& Sheldon, 2011; Seligman et al., 2005), practicing optimistic thinking (Boehm et al., 2011a; King, 2001; Layous, Nelson, \& Lyubomirsky, 2013; Lyubomirsky et al., 2011; Sheldon \& Lyubomirsky, 2006), doing acts of kindness (Nelson et al., 2012; Dunn, Aknin, \& Norton, 2008; Layous, Nelson, Oberle, Schonert-Reichl, \& Lyubomirsky, 2012; Sheldon, Boehm, \& Lyubomirsky, 2012, Study 2), affirming one's most important values Nelson, Fuller, Choi, \& Lyubomirsky, 2014), using one's signature strengths in new ways (Seligman et al., 2005), practicing self-compassion (Neff, Kirkpatrick, \& Rude, 2007), and meditating on loving feelings toward oneself and others (Fredrickson, Cohn, Coffey, Pek, \& Finkel, 2008). 


\section{How and Why Do Positive Activities Improve Happiness?}

An important goal of advancing psychological science regarding the pursuit of happiness is not only to understand what makes people happier but also to understand the mediating factors that lead to greater happiness-in other words, how and why positive activities (the intentional actions that people take to become happier) make people happier. This approach is akin to medical researchers attempting to discover the active ingredients in effective medications and treatments. For example, at one time, scurvy (a disease caused by Vitamin C deficiency) was prevalent among sailors who were unable to carry perishable fruits and vegetables on long voyages. Sailors soon learned that eating citrus fruits cured the disease, yet many years passed before they grasped that the Vitamin $\mathrm{C}$ that is abundant in such fruits explained the cure. Similarly, happiness researchers are currently exploring the possible mechanisms or active ingredients that explain the effectiveness of positive activities to enhance happiness.

The positive activity model (Lyubomirsky \& Layous, 2013) was developed to better understand the mediating variables that explain how and why positive activities work to improve happiness. The model proposes that positive activities give rise to greater positive emotions, positive thoughts, positive behaviors, and satisfaction of basic needs, which, in turn, foster happiness. In other words, just as improved levels of Vitamin C explained how and why eating citrus fruit led to the reduction of scurvy, the model posits that more positive emotions, positive thoughts, positive behaviors, and need satisfaction explain how and why performing positive activities leads to greater happiness.

If a presumed positive activity - whether it involves practicing optimism, meditation, gratitude, or kindness - fails to boost positive emotions, positive thoughts, positive behaviors, and satisfaction of basic needs, the individual's attempt at becoming happier will be futile. For example, a high school graduate who diligently writes thank-you notes to friends and family who supported her and bestowed gifts because her parents have instructed her to do so would not become happier if she did not actually feel more grateful. Thus, it is possible to perform a positive activity (e.g., writing gratitude letters) but not experience greater positive emotions and so forth, and, as a result, fail to achieve more happiness. Along the same line, when people engage in activities that fit better with their personalities and interests, they show larger well-being gains (Dickerhoof, 2007).

Several studies have shown preliminary support for the positive activity model. Providing evidence for the mediating role of positive emotions, one 
study found that participants who practice gratitude or optimism become happier over time, and that this effect is mediated by their ability to derive positive emotions from their daily experiences and to find those experiences satisfying (Lyubomirsky \& Dickerhoof, 2010). In another study, participants who received social support for performing acts of kindness became happier over a 9-week period, and this effect was mediated by their enjoyment of the kindness activity (Della Porta, 2013).

Studies also suggest that positive activities improve well-being because they foster the satisfaction of three basic human needs (Deci \& Ryan, 2000): autonomy (feeling in control of one's environment), relatedness (feeling close and connected to others), and competence (feeling effective and skilled). For example, in one experiment, expressing gratitude and optimism increased the need for satisfying feelings of autonomy and relatedness (but not competence), which, in turn, led to increased well-being (Boehm, Lyubomirsky, \& Sheldon, 2011b). Similarly, another study found that students who were prompted to set and pursue goals to enhance their autonomy or relatedness increased in well-being over a 6-month period, compared to students who were prompted to change something about their life circumstances (Sheldon et al., 2010).

In sum, several studies have provided preliminary empirical support for the mediating variables of the positive activity model. In particular, these studies suggest that one reason people become happier when they partake of happiness-enhancing strategies is that those strategies increase their levels of positive emotions, as well as their need satisfying feelings of autonomy and relatedness. More work is needed to investigate other mediators proposed by the model—specifically, positive thoughts (e.g., "I'm loved") and positive behaviors (e.g., healthy eating or higher work productivity). Furthermore, researchers do not yet fully understand the causal role of the mediating factors that lead to improved well-being. Just as randomized controlled trials are essential to understand the causal effect of a positive activity, they are also needed to understand the causal role of mediating variables (Rosenthal \& Rosnow, 2008). To establish that the mediating variables (e.g., positive emotions or feelings of relatedness) bring about greater happiness, future investigators should compare the happiness levels of participants who have been prompted to experience higher levels of such variables with those who have been instructed to engage in a neutral activity.

\section{How Can Positive Activities Be More Effective?}

Scientists have demonstrated how and why positive activities improve wellbeing and identified specific ways that people can perform positive activities 
to enhance their effectiveness. Specifically, this research suggests that the most efficacious positive activity will be performed by an individual who is motivated to fully engage in the activity (Lyubomirsky et al., 2011) and performs it with variety (Sheldon et al., 2012; Lyubomirsky, Sheldon et al., 2005) and appropriate timing (Lyubomirsky, Sheldon et al., 2005).

\section{Motivation and effort}

Researchers have shown that people who are motivated to become happier and summon effort toward achieving that goal will reap relatively more benefits from positive activities. In one investigation, students elected to participate in either a study described as a "happiness activity" (and were presumably motivated to become happier) or in a study described as "cognitive exercises" (and were presumably relatively unmotivated to become happier) (Lyubomirsky et al., 2011). Students who were motivated to pursue happiness showed greater gains in well-being after engaging in positive activities (in this case, expressing gratitude or optimism) than after engaging in control activities. In addition, as students mustered more effort in participating in the optimism and gratitude activities (judged by independent raters), they showed greater increases in well-being. Notably, however, motivation in this study was inferred from individuals' choices to participate in one of two groups (rather than being determined by random assignment), which limits the causal conclusions that can be made.

\section{Variety}

Practicing a positive activity with variety leads to greater happiness gains than practicing the activity in the exact same way each time. Instilling variety into a positive activity (e.g., doing acts of kindness) allows that activity to remain fresh, interesting, and rewarding (Berlyne, 1970; Pronin \& Jacobs, 2008; Rolls, Rolls, Rowe, \& Sweeney, 1981) and decreases the chances that it becomes dull and boring, such that the individual adapts to it (Frederick \& Loewenstein, 1999; see also Helson, 1964; Parducci, 1995). Two recent investigations have demonstrated the role of variety in enhancing well-being (Sheldon et al, 2012). In the first study, people who reported making a life change (e.g., joining a sorority) that enhanced the variety in their day-to-day lives (e.g., preparing for new events and interacting with new people) showed relatively bigger boosts in positive emotions. In a second study, participants who were instructed to vary their kind acts over the course of a 10-week acts of kindness intervention reported increases in well-being, whereas participants who were prompted to perform the same 
acts each week actually became less happy (Sheldon et al., 2012). These findings suggest that individuals can enhance their happiness by varying strategies and positive activities - in sequence or concurrently-that promote happiness. Indeed, research with large and diverse samples shows that happiness seekers typically practice up to eight strategies (e.g., doing kind acts, expressing gratitude, etc.) during a given period of time (e.g., within a week or month) to improve their happiness (Parks, Della Porta, Pierce, Zilca, \& Lyubomirsky, 2012).

\section{Timing}

Multiple studies have demonstrated the importance of practicing positive activities with appropriate timing. One experiment manipulated timing by instructing participants to count their blessings either three times per week or once per week (Lyubomirsky, Sheldon et al., 2005). Interestingly, participants who counted their blessings once a week showed significantly larger increases in happiness than those who performed a neutral activity, but this difference was not observed among participants who counted their blessings three times a week. Participants who counted their blessings weekly may have found the practice more fresh, meaningful, and rewarding, whereas those who counted their blessings three times a week may have found the activity boring or had difficulty generating things for which to be grateful.

In another investigation, students were asked to perform five acts of kindness all in one day (e.g., all on Thursday) or throughout the week (Lyubomirsky, Sheldon et al., 2005). Those who performed all five acts of kindness in one day showed happiness gains over the course of the study, but those who spread their kind acts across the week did not show such gains. Carrying out multiple acts of kindness during a single day may have produced relatively larger and more salient bursts of positive emotions than dispersing such acts. Although learning theory posits that distributing practices is most effective (Cepeda, Pashler, Vul, Wixted, \& Rohrer, 2006), emotion researchers have found that experiencing more positive emotions than negative emotions is optimal for human flourishing (Fredrickson, 2013; Fredrickson \& Losada, 2005), and performing multiple kind acts in a given day likely increases the ratio of positive to negative emotions. Furthermore, such bursts may have precipitated upward spirals-for example, feeling appreciated or proud on Thursday may have enhanced a person's creativity or a close relationship on the same day, which may have resulted in even more positive emotions on Friday, and so on (cf. Fredrickson \& Joiner, 2002). Because this finding has not yet been replicated, however, future studies are needed to illuminate the mechanisms involved. 


\section{Person-Activity Fit}

Some people may benefit more or less from practicing various positive activities than others. Accordingly, the extent to which an activity matches a person's personality, resources, goals, values, and preferences is an important factor that impacts the success of any activity. For example, extraverts may benefit relatively more from a social activity (e.g., doing kind acts), whereas introverts may benefit relatively more from a reflective activity (e.g., visualizing their best possible selves). We term this concept person-activity fit (Lyubomirsky, 2008; Lyubomirsky, Sheldon, et al., 2005), with greater fit predicting greater benefit from the activity (Sin, Della Porta, \& Lyubomirsky, 2011).

In one test of person-activity fit, participants were assigned to engage in a positive activity based on their previously reported activity preferences or based on random selection. Participants who were matched to an activity based on their preferences (and presumably experienced greater fit with the activity) reported greater boosts in well-being than those who were randomly assigned to an activity (Schueller, 2011). Similarly, another study found that performing a happiness-increasing activity that fit students' personalities and interests (i.e., they enjoyed it and it felt natural to them) led to greater gains in well-being relative to practicing a poor-fitting happiness activity or a control activity (Dickerhoof, 2007). These findings support the hypothesis that person-activity fit moderates—or influences—activity effectiveness.

\section{Summary}

In sum, multiple studies have evaluated the most effective ways to perform positive activities so that people can profit the most from such activities, garnering the most impressive and most lasting benefits. To date, scientists have identified important empirically supported variables related to enhancing happiness that include practicing the activity with motivation and effort, with the appropriate timing and variety, and choosing an activity that fits one's personality and goals. For more detailed discussions of these and other factors, see Layous and Lyubomirsky (2014) and Nelson and Lyubomirsky (2014).

\section{Evaluating Popular Claims About Becoming Happier}

Because happiness is a popular topic and near-universal goal, and because the secret to a happy life may seem obvious or easy, many popular claims exist about ways that people can become happier. Three such claims, which 
we evaluate below, include the idea that money can buy happiness, that following self-help recommendations will improve happiness, and that more happiness is always better.

\section{Hedonic Adaptation and Its Implications for "Buying" Happiness}

When considering what it might take to make them happier, most people put "more money" at the top of their lists. Although money and happiness are indeed related, the correlation is not particularly strong (for a review, see Diener \& Biswas-Diener, 2002). Moreover, because almost all investigations of the link between money and happiness are correlational, one cannot assume that money (versus some other related factor) causes greater happiness. In fact, some research indicates the opposite-happier people are more likely to earn more money (see Lyubomirsky, King, \& Diener, 2005, for a meta-analytic review).

One reason for the relatively low correlation between money and happiness is that over time people begin to take their income level and standard of living for granted (Lyubomirsky, 2011). Research suggests that life's joys and sorrows abate with time-a phenomenon known as hedonic adaptation. Specifically, hedonic adaptation is the process by which the emotional effects of a stimulus, like the size of one's bank account, attenuate over time (Frederick \& Loewenstein, 1999; Wilson \& Gilbert, 2008). Many studies have demonstrated that people inevitably adapt to positive and negative events, such as marriage, birth of a child, promotion, divorce, widowhood, and winning the lottery (Boswell, Boudreau, \& Tichy, 2005; Brickman, Coates, \& Janoff-Bulman, 1978; Lucas, 2007). Indeed, hedonic adaptation poses a specific challenge to achieving lasting happiness because people may even adapt to their attempts to becoming happier (see Jacobs Bao, \& Lyubomirsky, in press, for a review).

The notion of hedonic adaptation can be invoked to explain the association between money and happiness. Research suggests that even if people experience a boost in happiness after a promotion and raise, they will quickly adapt to their new income, as they begin to compare themselves to betterheeled colleagues and will begin to desire an even larger salary. The best way to derive happiness from money, then, may be to spend it on things that are resistant to adaptation. For example, spending discretionary income on other people has been shown to provide lasting mood increases, presumably because this sort of spending strengthens interpersonal relationships and sets into motion upward spirals of gratitude (Algoe, Haidt, \& Gable, 2008; Dunn et al., 2008). Also, research suggests that spending money on life experiences 
rather than material possessions provides more long-lasting happiness (Van Boven \& Gilovich, 2003). Even the most state-of-the-art home entertainment system will quickly become a dusty background fixture in one's living room. However, memories of seeing one's favorite band or reminiscences of a travel adventure are relatively more enduring. Moreover, whereas the home entertainment system can only depreciate with time, positive memories are prone to a rosy view in which they actually get better over time (Mitchell, Thompson, Peterson, \& Cronk, 1997). In short, although receiving a hike in one's paycheck does not guarantee a corresponding hike in happiness, money can promote happiness if that money is spent wisely (see Dunn, Gilbert, \& Wilson, 2011, for a review).

\section{The Self-Help Literature}

The popularity and availability of self-help books render them a common approach that people use to improve their happiness (Bergsma, 2008). As mentioned previously, however, many self-help books are not backed by scientific evidence and do not undergo the type of peer review required by academic journals. Accordingly, an incredibly wide variety of books are available that claim to have uncovered the key to a happy life. For example, a popular self-help book, The Secret (Byrne, 2006), contends that the world operates by a law of attraction, and that, by this law, people's thoughts attract specific outcomes-including health, wealth, and happiness. Accordingly, people can attract happiness by simply wishing it. To the contrary, research suggests that people should actively engage in behaviors (e.g., performing kind acts or writing gratitude letters to close others) to change their lives for the better and thereby become happier (Lyubomirsky, 2008). This is just one example of many of why consumers of self-help should be particularly cautious when evaluating self-help books and choosing empirically validated recommendations.

\section{Potential Costs of Actively Pursuing Happiness}

One concern with the self-help literature is that it can send the message that happiness is always good, and that people should attempt to max out on happiness. This notion has recently been called into question, with the suggestion that the pursuit and attainment of happiness may have caveats or downsides. For example, recent work indicates that people who value happiness too much experience less happiness in response to a positive experience (Mauss, Tamir, Anderson, \& Savino, 2011) and are more likely to suffer from depression (Ford, Shallcross, Mauss, Floerke, \& Gruber, 2012). Other 
research has indicated that too much happiness may be detrimental in certain problem-solving situations (e.g., when calculating one's taxes) and social contexts (e.g., when comforting a grieving friend) (see Gruber, Mauss, \& Tamir, 2011, for a review).

Although, at first glance, these findings appear to challenge some of the research cited in this chapter, we believe that the two perspectives are not incongruent. First, we do not suggest that people should pursue happiness via positive activities without end, or that they should attempt to eliminate negative emotions altogether. Indeed, recent studies reveal that the optimal level of happiness is an " 8 out of 10 " (rather than a "10 out of 10 "; Oishi, Diener, \& Lucas, 2007), and that experiencing frequent mild positive emotions along with occasional negative emotions is the most adaptive combination (Diener \& Oishi, 2011).

Second, our work suggests that if people focus on being more grateful, optimistic, and kind (rather than focusing on the end state and continually asking themselves if they're "happy yet"), then they can become lastingly happier. This is a notably different approach from being preoccupied with happiness as an end in itself, which may be problematic (Schooler \& Mauss, 2010). Certainly, constantly monitoring and trying to control one's happiness levels while engaging in a rewarding activity or helping others is likely to be counterproductive.

\section{Mental Health: The Positive Psychological Perspective}

Positive psychological science is a relatively new development within psychology. In the 20th century, researchers focused almost exclusively on understanding and alleviating mental illness, rather than focusing on what makes life worth living (Seligman \& Csikszentmihalyi, 2000). Along with the birth of positive psychology came a renewed focus (at least in the psychological literature) on what it means to be mentally healthy.

Because past work focused primarily on alleviating mental health conditions, psychological wellness came to be defined by an absence of disease. Positive psychological research, however, has taken the concept of wellness one step further, capitalizing on the observation that people do not just want to be "not depressed" but to be happy. Accordingly, positive activities aim to help people achieve happiness, rather than simply alleviating such conditions as depression, anxiety, and addiction.

One common lay belief is that the pursuit of happiness is a luxury-a pastime reserved for those who have attained a certain level of material comfort and physical well-being. Both Maslow's (1943) influential hierarchy of needs 
and an updated hierarchy informed by contemporary evolutionary perspectives (Kenrick, Griskevicius, Neuberg, \& Schaller, 2010) formalize this notion, positing that the pursuit of higher psychological needs (esteem, love) will be more successful only when lower level needs, such as self-protection and satiety, are met. A logical extension is that happiness-increasing activities may not be effective for those who are depressed or physically unwell. However, research suggests otherwise. Indeed, happiness interventions have proven effective (and sometimes even relatively more effective) for those with chronic illness (Emmons \& McCullough, 2003) and with mild-to-moderate depression (Seligman et al, 2005; Seligman, Rashid, \& Parks, 2006). In fact, evidence even shows that optimism and positive affect can aid in healing and recovery from physical ailments (see Cohen \& Pressman, 2006; Kiecolt-Glaser, McGuire, Robles, \& Glaser, 2002, for reviews).

\section{Case Study}

To illustrate how happiness-increasing practices should (and should not) be implemented in everyday life, consider Michelle, a hypothetical 38-year-old educated single woman who works as an office manager. Michelle has a comfortable life. She is not wealthy but has no debt and is able to afford to go out to occasional dinners with friends, pay for a gym membership, and take annual vacations. Her social life is reasonably full and she is healthy and fit.

Despite the objective goodness of her life, Michelle feels she is not as happy as she could be. As she reflects, she realizes that she is "in a rut" and has begun to take the positive things around her for granted. She confides in her friends and receives a wealth of well-meaning advice based on their personal experiences ("You should get a pet!" "Get rid of your TV!" "Go back to school!"). Overwhelmed, she goes to her local bookstore and browses the self-help aisle, searching for a more universal answer to the secret of happiness. She picks up one title, which promises surefire and easy techniques to increase happiness. The book is straightforward, and the author seems reputable, so she purchases it and reads it quickly and excitedly. She begins to put the recommended strategies into practice the very next day, feeling inspired and eager for transformation. To her delight, Michelle obtains an immediate boost to her general mood, yet, over a few weeks, the "thrill is gone." She realizes that she doesn't feel much different from before she started, her enthusiasm wanes, and she becomes increasingly frustrated ("I read the book; I'm following the advice. Why am I not happier?”). Eventually, she gives up completely. 
In discussing her experience with friends, Michelle likens it to a time she tried a fad diet. She began it with gusto, saw an immediate small benefit, but the diet became onerous and she stopped seeing results after a few weeks. So she gave up, gained the weight back, and felt like a failure. In the same way that her weight seemed stuck at a particular number, she concludes that maybe her happiness is similarly static. "Maybe I'm just not meant to be any happier," she remarks. "Happiness is something you either have or you don't."

Our research could offer Michelle some guidance on how to increase her happiness using potentially much more successful strategies. First, rather than seeking a one-size-fits-all approach to increasing happiness, she should take inventory of her personality and interests. Is she an introvert? If so, she might prefer to engage in a relatively more reflective happiness-increasing activity, such as keeping a gratitude journal. Is she active and outdoorsy? If so, she may enjoy volunteering to help maintain a local nature trail.

After she has identified an activity or two that may fit her well, she needs to consider the important question of exactly how she will enact the activities. Of course, in the same way that working out at the gym only once or twice will not lead to lasting health benefits, writing in a gratitude journal or volunteering is only likely to be beneficial if it is made habitual. However, due to hedonic adaptation, the danger of making something a habit is that it can become less fresh and rewarding over time. Therefore, Michelle should be discouraged from doing the same activity every day, in the exact same way. Instead, if she opts for a gratitude journal, she might decide to write in it only once or twice per week. She might also vary the topic she focuses on. One day she can write about her family, the next about her health, the next about her neighborhood, and so forth. If she chooses to volunteer on a nature trail, she may choose to do it only on the weekends, sometimes alone, sometimes in a group of like-minded peers. She may ask to work on different parts of the trail or to take on different tasks, to keep the experience novel and interesting.

Finally, Michelle seems to be very consciously and systematically monitoring her happiness levels, in the same way that a careful dieter monitors her weight. Such calculated monitoring is known to be counterproductive. Although this may be easier said than done, if Michelle could reframe her positive activities not as happiness-ensurers but as practices that may be rewarding in and of themselves, she may be more likely to experience happiness as a byproduct.

Note that the two activities we suggested for Michelle are quite simple cognitive and behavioral changes. We are not suggesting that Michelle change jobs, move to the seashore, or find Mr. Right in order to achieve 
happiness. Instead, simply reframing the way that Michelle thinks about and engages in her everyday life is likely to ultimately be beneficial.

\section{Concluding Remarks}

In a relatively short time, psychological science has made great strides in understanding how people can achieve happiness. Using some of the most effective methodologies available, researchers have found that happiness can be attained via simple, cost-effective, nonstigmatizing, self-directed activities, such as writing gratitude letters or keeping an optimism diary. Although research on happiness has come a long way in the last 2 decades, much more work remains. Future studies should continue to investigate how and why particular positive activities work to increase happiness and should continue to implement randomized controlled trials to understand the causal role of potential mechanisms or factors.

Unfortunately, limited self-knowledge and unwise decision making (e.g., Wilson \& Gilbert, 2005), combined with the well-meaning but often misguided claims from the self-help industry, can make the goal of lasting happiness seem frustratingly unattainable. Even for those positive strategies that seem intuitive, such as expressing gratitude, when and how to best enact such strategies is far from obvious. Our research has generated compelling evidence that when implemented correctly, happiness-increasing activities are quite effective at promoting positive and lasting changes. Science shows that happiness is indeed within each person's reach.

\section{References}

Algoe, S. B., Haidt, J., \& Gable, S. L. (2008). Beyond reciprocity: Gratitude and relationships in everyday life. Emotion, 8, 425-429.

Bergsma, A. (2008). Do self-help books help? Journal of Happiness Studies, 9, 341-360.

Berlyne, D. E. (1970). Novelty, complexity, and hedonic value. Perception \& Psychophysics, 8, 279-286.

Boehm, J. K., Lyubomirsky, S., \& Sheldon, K. M. (2011a). A longitudinal experimental study comparing the effectiveness of happiness-enhancing strategies in Anglo Americans and Asian Americans. Cognition \& Emotion, 25, 1263-1272.

Boehm, J. K., Lyubomirsky, S., \& Sheldon, K. M. (2011b). [The role of need satisfying emotions in a positive activity intervention]. Unpublished raw data.

Boswell, W. R., Boudreau, J. W., \& Tichy, J. (2005). The relationship between employee job change and job satisfaction: The honeymoon-hangover effect. Journal of Applied Psychology, 90, 882-892. 
Brickman, P., Coates, D., \& Janoff-Bulman, R. (1978). Lottery winners and accident victims: Is happiness relative? Journal of Personality and Social Psychology, 36, 917-927.

Byrne, R. (2006). The secret. New York, NY: Atria Books.

Cepeda, N. J., Pashler, H., Vul, E., Wixted, J. T., \& Rohrer, D. (2006). Distributed practice in verbal recall tasks: A review and quantitative synthesis. Psychological Bulletin, 132, 354-380.

Chancellor, J., Layous, K., \& Lyubomirsky, S. (2013). Recalling positive events at work makes employees feel happier, move more, and talk less: A 6-week randomized controlled intervention at a Japanese workplace. Manuscript under review.

Cohen, S., \& Pressman, S. D. (2006). Positive affect and health. Current Directions in Psychological Science, 15, 122-125

Deci, E. L., \& Ryan, R. M. (2000). The "what" and "why" of goal pursuits: Human needs and the self-determination of behavior. Psychological Inquiry, 11, 227-268.

Della Porta, M. D. (2013). Enhancing the effects of happiness-boosting activities: The role of autonomy support in an experimental longitudinal intervention. Dissertation Abstracts International: Section B. Sciences and Engineering, 73.

Dickerhoof, R. (2007). Expressing optimism and gratitude: A longitudinal investigation of cognitive strategies to increase well-being. Dissertation Abstracts International: Section B. Sciences and Engineering, 68, 4174.

Diener, E. (1984). Subjective well-being. Psychological Bulletin, 95, 542-575.

Diener, E. (2000). Subjective well-being: The science of happiness and a proposal for a national index. American Psychologist, 55, 34-43.

Diener, E., \& Biswas-Diener, R. (2002). Will money increase subjective well-being? A literature review and guide to needed research. Social Indicators Research, 57, 119-169.

Diener, E., \& Lucas, R. E. (1999). Personality and subjective well-being. In D. Kahneman, E., Diener, \& N. Schwarz (Eds.), Well-being: The foundations of hedonic psychology (pp. 213-229). New York, NY: Russell Sage.

Diener, E., \& Oishi, S. (2011). An evolutionary paradox? If happy people have better health, longevity, fecundity, and healthier children, why aren't we all happy? Unpublished manuscript, Department of Psychology, University of Illinois, Champaign, IL.

Diener, E., Oishi, S., \& Lucas, R. E. (2009). Subjective well-being: The science of happiness and life satisfaction. In C. R. Snyder \& S. J. Lopez (Eds.), Handbook of positive psychology (2nd ed., pp. 62-73). New York, NY: Oxford University Press.

Diener, E., Sandvik, E., Seidlitz, L., \& Diener, M. (1993). The relationship between income and subjective well-being: Relative or absolute? Social Indicators Research, 28, 195-223.

Diener, E., Suh, E. M., Lucas, R. E., \& Smith, H. L. (1999). Subjective well-being: Three decades of progress. Psychological Bulletin, 125, 276-302. 
Dunn, E. W., Aknin, L. B., \& Norton, M. I. (2008). Spending money on others promotes happiness. Science, 319, 1687-1688.

Dunn, E. W., Gilbert, D. T., \& Wilson, T. D. (2011). If money doesn't make you happy, then you probably aren't spending it right. Journal of Consumer Psychology, $21,115-125$.

Emmons, R. A., \& McCullough, M. E. (2003). Counting blessings versus burdens: An experimental investigation of gratitude and subjective well-being in daily life. Journal of Personality and Social Psychology, 84, 377-389.

Ford, B. Q., Shallcross, A. J., Mauss, I. B., Floerke, V. A., \& Gruber, J. (2012). If you seek it, it won't come: Valuing happiness is associated with symptoms and diagnosis of depression. Manuscript submitted for publication.

Frederick, S., \& Loewenstein, G. (1999). Hedonic adaptation. In D. Kahneman, E. Diener, \& N. Schwarz (Eds.), Well-being: The foundations of hedonic psychology (pp. 302-329). New York, NY: Russell Sage.

Fredrickson, B. L. (2013). Updated thinking on positivity ratios. American Psychologist, 68, 814-822.

Fredrickson, B. L., Cohn, M. A., Coffey, K. A., Pek, J., \& Finkel, S. M. (2008). Open hearts build lives: Positive emotions, induced through loving-kindness meditation, build consequential personal resources. Journal of Personality and Social Psychology, 95, 1045-1062.

Fredrickson, B., L., \& Joiner, T. (2002). Positive emotions trigger upward spirals toward emotional well-being. Psychological Science, 13, 172-175.

Fredrickson, B. L., \& Losada, M. F. (2005). Positive affect and the complex dynamics of human flourishing. American Psychologist, 60, 678-686.

Froh, J. J., Sefick, W. J., \& Emmons, R. A. (2008). Counting blessings in early adolescents: An experimental study of gratitude and subjective well-being. Journal of School Psychology, 46, 213-233.

Fujita, F., \& Diener, E. (2005). Life satisfaction set point: Stability and change. Journal of Personality and Social Psychology, 88, 158-164.

Gruber, J., Mauss, I. B., \& Tamir, M. (2011). A dark side of happiness? How, when, and why happiness is not always good. Perspectives on Psychological Science, 6, 222-233.

Helson, H. (1964). Current trends and issues in adaptation-level theory. American Psychologist, 19, 26-38.

Helson, R., Jones, C., \& Kwan, V. S. Y. (2002). Personality can change over 40 years of adulthood: Hierarchical linear modeling analyses of two longitudinal samples. Journal of Personality and Social Psychology, 83, 752-766.

Jacobs Bao, K., \& Lyubomirsky, S. (in press). Making happiness last. In A. Parks (Ed.), The handbook of positive interventions. New York, NY: Wiley-Interscience.

Kenrick, D.T., Griskevicius, V., Neuberg, S.L., \& Schaller, M. (2010). Renovating the pyramid of needs: Contemporary extensions built upon ancient foundations. Perspectives on Psychological Science, 5, 292-314.

Kiecolt-Glaser, J. K., McGuire L., Robles T., \& Glaser R. (2002). Emotions, morbidity, and mortality: New perspectives from psychoneuroimmunology. Annual Review of Psychology, 53, 83-107. 
King, L. A. (2001). The health benefits of writing about life goals. Personality and Social Psychology Bulletin, 27, 798-807.

Krueger, R. F., Hicks, B. M., \& McGue, M. (2001). Altruism and antisocial behavior: Independent tendencies, unique personality correlates, distinct etiologies. Psychological Science, 12, 397-402.

Layous, K., Lee, H. C., Choi, I., \& Lyubomirsky, S. (2013). Culture matters when designing a successful happiness-increasing activity: A comparison of the United States and South Korea. Journal of Cross-Cultural Psychology, 44, 1294-1303.

Layous, K., \& Lyubomirsky, S. (2014). The how, why, what, when, and who of happiness: Mechanisms underlying the success of positive activity interventions. In J. Gruber \& J. Moskowitz (Eds.), Positive emotion: Integrating the light and dark sides (pp. 473-495). Oxford, UK: Oxford University Press

Layous, K., Nelson, S. K., \& Lyubomirsky, S. (2013). What is the optimal way to deliver a positive activity intervention? The case of writing about one's best possible selves. Journal of Happiness Studies, 14, 635-654.

Layous, K., Nelson, S. K., Oberle, E., Schonert-Reichl, K. A., Lyubomirsky, S. (2012). Kindness counts: Prompting prosocial behavior in preadolescents boosts peer acceptance and well-being. PLOS ONE, 7, e51380.

Lucas, R. E. (2001). Pleasant affect and sociability: Toward a comprehensive model of extraverted feelings and behaviors. Dissertation Abstracts International, 61 (10-B), 5610. (UMI No. AAI9990068).

Lucas, R. E. (2007). Adaptation and the set-point model of subjective well-being: Does happiness change after major life events? Current Directions in Psychological Science, 16, 75-79.

Lucas, R. E., Diener, E., \& Suh, E. M. (1996). Discriminant validity of well-being measures. Journal of Personality and Social Psychology, 71, 616-628.

Lykken, D., \& Tellegen, A. (1996). Happiness is a stochastic phenomenon. Psychological Science, 7, 186-189.

Lyubomirsky, S. (2001). Why are some people happier than others? The role of cognitive and motivational processes in well-being. American Psychologist, 56, 239-249.

Lyubomirsky, S. (2008). The how of happiness: A scientific approach to getting the life you want. New York, NY: Penguin Press.

Lyubomirsky, S. (2011). Hedonic adaptation to positive and negative experiences. In S. Folkman (Ed.), Oxford handbook of stress, health, and coping. (pp. 200224). New York, NY: Oxford University Press.

Lyubomirsky, S., \& Dickerhoof, R. (2010). A construal approach to increasing happiness. In J. Tangney, \& J. E. Maddux (Eds.), Social psychological foundations of clinical psychology (pp. 229-244). New York, NY: Guilford Press.

Lyubomirsky, S., Dickerhoof, R., Boehm, J. K., \& Sheldon, K. M. (2011). Becoming happier takes both a will and a proper way: An experimental longitudinal intervention to boost well-being. Emotion, 11, 391-402.

Lyubomirsky, S., King, L. A., \& Diener, E. (2005). The benefits of frequent positive affect: Does happiness lead to success? Psychological Bulletin, 131, 803-855. 
Lyubomirsky, S., \& Layous, K. (2013). How do simple positive activities increase well-being? Current Directions in Psychological Science, 22, 57-62.

Lyubomirsky, S. Sheldon, K. M., Schkade, D. (2005). Pursuing happiness: The architecture of sustainable change. Review of General Psychology, 9, 111-131.

Lyubomirsky, S., Tkach, C., \& DiMatteo, M. R. (2006). What are the differences between happiness and self-esteem? Social Indicators Research, 78, 363-404.

Maslow, A.H. (1943). A theory of human motivation. Psychological Review, 50, 370-396.

Mauss, I. B., Tamir, M., Anderson, C. L., \& Savino, N. S. (2011). Can seeking happiness make people unhappy? Paradoxical effects of valuing happiness. Emotion, 11, 807-815.

Mitchell, T. R., Thompson, L., Peterson, E., \& Cronk, R. (1997). Temporal adjustment of the evaluation of events: The "rosy view." Journal of Experimental Social Psychology, 33, 421-448.

McCrae, R. R., \& Costa, P. T. (1990). Personality in adulthood. New York, NY: Guilford Press.

McCullough, M. E., Emmons, R. A., \& Tsang, J.-A. (2002). The grateful disposition: A conceptual and empirical topography. Journal of Personality and Social Psychology, 82, 112-127.

Neff, K. D., Kirkpatrick, K. L., \& Rude, S. S. (2007). Self-compassion and adaptive psychological functioning. Journal of Research in Personality, 41, 139-154.

Nelson, S. K., Della Porta, M. D., Jacobs Bao, K., Lee, H. C., Choi, I., \& Lyubomirsky, S. (2012). "It's up to you": Experimentally manipulated autonomy support for prosocial behavior improves well-being in two cultures over six weeks. Manuscript submitted for publication.

Nelson, S. K., Fuller, J. A., Choi, I., \& Lyubomirsky, S. (2012). The positive psychology of self-affirmation: The role of need satisfaction, meaning, and flow. Manuscript in preparation.

Nelson, S. K., \& Lyubomirsky, S. (2014). Finding happiness: Tailoring positive activities for optimal well-being benefits. In M. Tugade, M. Shiota, \& L. Kirby (Eds.), Handbook of positive emotions (pp. 275-293). New York, NY: Guilford.

Nes, R. B., Roysamb, E., Tambs, K., Harris, J. R., \& Reichborn-Kjennerud, T. (2006). Subjective well-being: Genetic and environmental contributions to stability and change. Psychological Medicine, 36, 1033-1042.

Oishi, S., Diener, E., \& Lucas, R. E. (2007). The optimum level of well-being: Can people be too happy? Perspectives on Psychological Science, 2, 346-360.

Parducci, A. (1995). Happiness, pleasure, and judgment: The contextual theory and its applications. Mahwah, NJ: Erlbaum.

Parks, A. C., Della Porta, M. D., Pierce, R. S., Zilca, R., \& Lyubomirsky, S. (2012). Pursuing happiness in everyday life: The characteristics and behaviors of online happiness seekers. Emotion, 12, 1222-1234.

Pronin, E., \& Jacobs, E. (2008). Thought speed, mood, and the experience of mental motion. Perspectives on Psychological Science, 3, 461-485. 
Roberts, B. W., Walton, K. E., \& Viechtbauer, W. (2006). Patterns of mean-level change in personality traits across the life course: A meta-analysis of longitudinal studies. Psychological Bulletin, 132, 1-25.

Rolls, B., J., Rolls, E. T., Rowe, E. A., \& Sweeney, K. (1981). Sensory specific satiety in man. Physiology \& Behavior, 27, 137-142.

Rosenthal, R., \& Rosnow, R. L. (2008). Essentials of behavioral research (3rd ed.). Boston, MA: McGraw-Hill.

Ryan, R. M., \& Deci, E. L. (2001). On happiness and human potentials: A review of research on hedonic and eudaimonic well-being. Annual Review of Psychology, 52, 141-166.

Ryff, C. D. (1989). Happiness is everything, or is it? Explorations on the meaning of psychological well-being. Journal of Personality and Social Psychology, 57, 1069-1081.

Schooler, J. W., \& Mauss, I. B. (2010). To be happy and to know it: The experience and meta-awareness of pleasure. In M. L. Kringelbach \& K. C. Berridge (Eds.), Pleasures of the brain (pp. 244-254). Oxford, UK: Oxford University Press.

Schueller, S. M. (2011). To each his own well-being boosting intervention: Using preference to guide selection. The Journal of Positive Psychology, 6, 300-313.

Seligman, M. E. P., \& Csikszentmihalyi, M. (2000). Positive psychology: An introduction. American Psychologist, 55, 5-14.

Seligman, M. E. P., Rashid, T., \& Parks, A. C. (2006). Positive psychotherapy. American Psychologist, 61, 774-788.

Seligman, M. E. P., Steen, T. A., Park, N., \& Peterson, C. (2005). Positive psychology progress: Empirical validation of interventions. American Psychologist, 60, 410-421.

Sheldon, K.M., Abad, N., Ferguson, Y., Gunz, A., Houser-Marko, L., Nichols, C. P., \& Lyubomirsky, S. (2010). Persistent pursuit of need satisfying goals leads to increased happiness: A 6-month experimental longitudinal study. Motivation \& Emotion, 34, 39-48.

Sheldon, K. M., Boehm, J. K., \& Lyubomirsky, S. (2012). Variety is the spice of happiness: The hedonic adaptation prevention (HAP) model. In I Boniwell \& S. David (Eds.), Oxford handbook of happiness (pp. 901-914). Oxford: Oxford University Press.

Sheldon, K. M., \& Lyubomirsky, S. (2006). How to increase and sustain positive emotion: The effects of expressing gratitude and visualizing best possible selves. The Journal of Positive Psychology, 1, 73-82.

Sin, N. L., Della Porta, M. D., \& Lyubomirsky, S. (2011). Tailoring positive psychology interventions to treat depressed individuals. In S. I. Donaldson, M. Csikszentmihalyi, \& J. Nakamura (Eds.), Applied positive psychology: Improving everyday life, health, schools, work, and society (pp. 79-96). New York, NY: Routledge.

Sin, N. L., \& Lyubomirsky, S. (2009). Enhancing well-being and alleviating depressive symptoms with positive psychology interventions: A practice-friendly metaanalysis. Journal of Clinical Psychology: In Session, 65, 467-487. 
Van Boven, L., \& Gilovich, T. (2003). To do or to have? That is the question. Journal of Personality and Social Psychology, 85, 1193-1202.

Walsh, R. (2011). Lifestyle and mental health. American Psychologist, 66, 579-592. Wilson, T. D., \& Gilbert, D. T. (2005). Affective forecasting: Knowing what to want. Current Directions in Psychological Science, 14, 131-134.

Wilson, T. D., \& Gilbert, D. T. (2008). Explaining away: A model of affective adaptation. Perspectives on Psychological Science, 3, 370-386. 